\title{
Hermeneutics Study and Educational Value of Suluk Wayang Surakarta Style
}

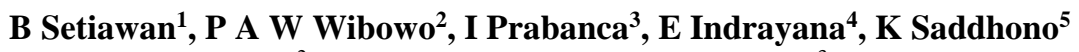 \\ $\left\{{ }^{1}\right.$ kaprodipbi@staff.uns.ac.id, ${ }^{2}$ prasetyoadiwisnuwibowo@yahoo.co.id, ${ }^{3}$ inprabancana@gmail.com, \\ ${ }^{4}$ erwinindrayana@student.uns.ac.id, ${ }^{5}$ kundharu_s@staff.uns.ac.id\} \\ 1,2,3,4,5 Universitas Sebelas Maret Surakarta, Indonesia
}

\begin{abstract}
Wayang is an originating art form from Javanese culture. The purpose of this research is to describe and explain in more depth about the Suluk Wayang Surakarta. This study of suluk discusses the forms and meanings of the Wayang Surakarta style reviewed from the perspective of the language used. Furthermore, the philosophy of the Wayang Surakarta style is also discussed. This study uses qualitative methods to describe and explain the form and meaning in the Wayang Surakarta style, the philosophy, and assess the value of education. The results of this study show that the language in the Suluk Wayang Surakarta is in the form of an archaic language which contains prayers to the Almighty God. Suluk also has a distinctive tone, different from suluk from other regions because it is influenced by the Surakarta Palace. The philosophy contained in this suluk comes from Javanese culture and reflects the personality and character of the Javanese community. The implications of this study contribute to the wealth of local wisdom of Javanese culture and religious values in character education.
\end{abstract}

Keywords: Wayang, Hermeneutic, Educational Value, Suluk, Surakarta

\section{INTRODUCTION}

Wayang is one of the world cultural heritage owned by Indonesia. This inheritance becomes very valuable because it contains noble values. The noble values possessed by wayang are not only in terms of figures that reflect human nature in life, but also have stories that contain cultural values, traditions, education, and moral teachings.

Judging from its form, puppets can be identified by two types, namely wayang wong (human) and wayang kulit. Wayang wong is a puppet whose character is human. Another case with wayang kulit is a shadow puppet whose form is a puppet from the leather and is driven by a dalang (puppeteer), that is, a person who moves and plays the dialogue of the story of the puppet characters.

Wayang kulit has experienced a glory in the past, even during the spread of Islam on the island of Java, the guardians used stories and puppet shows that have been inserted by Islamic teachings and rules as a medium for the spread of Islam, this can be realized because Wayang stories have stories depicting human life that teaches us to live life on the right path, in which case Islam also teaches the same thing so that it is easy for the saints to incorporate Islamic teachings into puppet stories [1]. The method proved to be quite successful, because at that time, 
shadow puppet shows were a means of entertainment for people who could embrace the wider community. In its development, leather puppet shows experienced a lot of decline in their specialization. This reduction in specialization can be caused by ignorance of the community about the storyline and characters of those who play a role in the story of the puppet show. The lack of knowledge about this makes many people feel reluctant and lazy to see the puppet show [2]. Even though the characters of each character in each puppet show are very good for life guidance for the community, some famous figures in the puppet stories are Pandavas and Kuravas. Pandavas are the main characters who always get bad treatment from the evil Kurawa, but at the end of the story Pandavas can win the battle and take over the kingdom they are entitled to.

Wayang are often used as media to convey messages and values of moral education that are noble for humans to live their lives [3]. The messages are conveyed explicitly or explicitly and are packaged in the form of a song called tembang or sekar. This song can be in the opening position, the core of the story, or at the end of the story.

This research focuses on discussing the wayang or tembang songs sung at the opening of the wayang story in the typical style of Surakarta City. The Suluk wayang Surakarta style has a distinctiveness that is at in the language section used in the Suluk Surakarta style [4]. In addition, the Suluk Surakarta style is also related to Surakarta style and gagrag or pakeliran style. This is what distinguishes between Surakarta style suluk wayang with puppet shows from other regions, such as Yogyakarta and East Javanese style puppet. The discussion on the Surakarta style of wayang puppets in this study focused more on the discussion of the use of language which contained several moral teachings and educational values that originated in Javanese culture.

\section{RESEARCH METHOD}

This research is a descriptive- qualitative study with a hermeneutic approach from the Suluk Wayang Surakarta style. The research data was obtained from direct observation by watching the shadow puppet performance held in Surakarta City. The research location is in Surakarta City, Central Java Province, Indonesia. The sampling technique of this research was purposive sampling by identifying only the suluk parts. The validity of the data is done by triangulating the theories, methods, and resource persons from the mastermind, the puppet expert, and the surrounding community as the puppet show lovers.

\section{RESULT AND DISCUSSION}

Wayang are generally known by three styles, namely Surakarta style, Yogyakarta style, and East Javanese style. Each style has a kind of rules or waton which are then used as guidelines for adherents. To differentiate between styles with one another, it can be viewed from the elements of work on pakeliran such as sabet (motion), catur (language) and iringan (karawitan) including sulukan. Sulukan is a mastermind vocal song to give a certain atmosphere effect in a wayang show, which has a very important role, as a maker, sweetener, amplifier, and builder of the scene [4]. The atmosphere of the scene in question includes an atmosphere of happiness, relief (calm), peace, sadness, mangu, emeng, anger, prenes (love), greget (surprised), and so forth.

Sulukan in wayang performances is able to color the events of the play presented by the puppeteer [5]. Others say that sulukan is a classic fragment of poetry commonly used in puppet shows. 
In the Surakarta style wayang show, the tradition is divided into three pathets, namely Pathet Nem, Pathet Sanga, and Pathet Manyura. Pathet Nem has a base note 2 (gulu), Pathet Sanga has a base note 5 (five) or 1 (item), while the Pathet Manyura has a base note 6 (nem) [6]. Pathet's position is very important in relation to sulukan, through dalang grimingan easily adjusts the tone in making sulukan, so that it is not wrong to determine the suluk force. The pathet referred to in this case is that besides being referred to as the boundary of the gending region, also as a pointer to the basic tone of sulukan it is usually called grimingan and or tintingan gender instruments.

The Surakarta style is composed of three types, namely: Pathetan, Sendhon, and Ada-ada. Pathetan is a dalang vocal lagon accompanied by certain gamelan sounds, such as gender, gambang, suling, rebab, kempul, kenong, and gong [7]. This type of sulukan has the impression and / or calm atmosphere, squad, relief, and so on. Sendhon has sad impressions, mangu, prenes and so on. The Ricikan gamelan used to accompany the sendhon is basically the same as pathetan, except that sulukan sendhon is not accompanied by rebab. Whereas there are vowels that begin with dhodhogan/ keprakan by dalang, accompanied by gamelan sounds, such as gender, kempul, kenong and gong usually to express the atmosphere of anger and grief, sereng, and so on [8].

The sulukan function can be viewed from structural functions and aesthetic functions. The structural function in question is the use of sulukan which is directly related to pakeliran, when sulukan is used, while the aesthetic function means sulukan which is displayed to support the ongoing atmosphere, for example sulukan as a maker, sweetener, atmosphere builder and so on [9]. The type and function of sulukan, are then used as guidelines for mastermind to work that is tailored to each taste or stability. The emergence of creativity from each puppeteer, resulting in the emergence of interesting phenomena to be discussed.

Here are some excerpts from suluk wayang.

\subsection{Suluk Pathetan \\ Leng-leng ramya ningkan, \\ Sasangka kumenyar, o, \\ Mangrengga ruming puri, o, \\ Mangkin tanpa siring, \\ Halep ingkang umah, \\ Maslir murubing langit, o, \\ Tekyan sarwa manik,o,o, \\ Tawingnya sinawung,o,o, \\ Saksat sekar sinuji, \\ Ungyan Banuwati,o, \\ Yan amren alangen, \\ Lan nata Duryudana,o, \\ Lan nata Duryudana,ooo..}

The above verses if interpreted literally have the meaning as follows. Fascinated by the beauty of the moon that illuminated the castle so much more beautiful, there is nothing like the beauty of the castle (the golden house) as light of the sky. Furthermore, the curtains are coated (gilded) of various gems like floral embroidery from gold thread. There is a bed and love with Duryudana.

From the above literal meaning as a whole if we live and we feel behind it contains the meaning or impression of calm, dignity, greatness, grayness, and so on, so that it is right when 
used in the first row (having an atmosphere of authority). Thus, between the head and the song, it can be right (grow) with the atmosphere of the scene.

\subsection{Suluk Sendhon}

Sulukan Sendhon Tlutur in pakeliran is also often used for Ada-ada. Call the Tlutur Sendhon usually using cakepan as below:

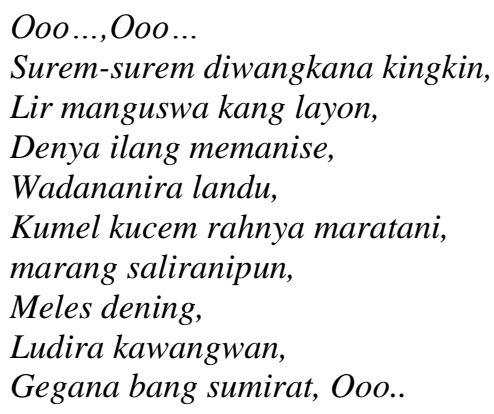

It is usually used in sad, terenyuh, nges, or clarity situations. Seen from the front, the impression is sad, especially if strengthened or strengthened with the song will be more pronounced. In the Kraton Sulukan tradition, Sendhon Tlutur is only accompanied by certain musical instruments such as the gender of barung, gambang and suling. In contrast to the tradition outside the palace, besides using the sound of gender, gambang, and suling, it also uses the sound of rebab, because to express sadness, the sound of the fiddle will be closer or more striking. The presence of ricikan or rebab instruments is expected to add to the beauty and nges of the atmosphere of the story, so that it is more appropriate to be used to accompany sulukan who has the impression of sadness [10]-[12].

Why in the sulukan tradition did Sendhon Tlutur not use the fiddle of rebab. In this case there are several different reasons. B. Murtiyoso said, if seen from the elements of the iringan, the sendhon tlutur does not use rebab, because working on his gender uses a sprinkling of pipilan, besides that the tempo is faster than the pathetan, so it is difficult to cause it. If the sulukan iringan of Sendhon Tlutur uses a rebab instrument, it will be sadder.

Furthermore, why sulukan tlutur sendhon is also used to exist. As mentioned above, this sulukan has the impression of feeling sad or sad. People who are sad, must be feeling confused, chaotic, must be how, what steps should be taken, want to be resolved immediately, it seems there is no kind of certainty [13]-[15]. In this suluk there is a chaotic impression, in a hurry not calm, noisy, and so on. From the impression of the taste, so that the cakepan can be used in existing sulukan, meaning the taste of cakepan can adjust to the taste of the song.

\section{CONCLUSIONS}

The world of wayang is categorized as performance art. Puppet performance is no different from the others, which still has an opening, core, and end structure. The opening of the puppet is called suluk. Suluk is a form of song in which in the Surakarta style there is sulukan pathet, sendhon, and ada-ada. This Suluk functions structurally and aesthetically, meaning sulukan has a function as an introduction between stories that will be brought by the dalang (puppeteer) and in it there is beauty because it is packaged and sung with a song. 


\section{REFERENCES}

[1] E. Herlyana, "Pagelaran Wayang Purwa sebagai Media Penanaman Nilai Religius Islam pada Masyarakat Jawa," THAQAFIYYAT J. Bahasa, Perad. dan Inf. Islam, vol. 14, no. 1, pp. 127-144, 2016.

[2] A. Djajasoebrata, Shadow theatre in Java: the puppets, performance and repertoire. Pepin Press, 1999.

[3] M. I. Cohen, "Wayang Kulit in Java Today," Routledge Companion to Puppetry Mater. Perform., p. 178, 2014.

[4] Y. P. Ardhi, "Wayang kulit sebagai media dakwah: studi pada wayang kulit dalang ki sudardi di desa pringapus semarang," 2010.

[5] N. Sahid and R. Lanjari, "The Existence of Wayang Orang Ngesti Pandhawa in Economic Change," in 2nd International Conference on Arts and Culture (ICONARC 2018), 2019.

[6] M. Perlman, "The social meanings of modal practices: status, gender, history, and pathet in Central Javanese music," Ethnomusicology, vol. 42, no. 1, p. 45, 1998.

[7] E. Suwatno, "Wacana Suluk Pedalangan Dalam Bahasa Jawa Berdasarkan Bentuk Dan Fungsinya [Suluk Pedalangan Discourse in Javanese Language Based on Forms and Functions]," TOTOBUANG, vol. 5, no. 1, pp. 45-55, 2018.

[8] B. Brinner, "At the Border of Sound and Silence: The Use and Function of Pathetan in Javanese Gamelan," Asian Music, vol. 21, no. 1, pp. 1-34, 1989.

[9] K. M. Newton, Interpreting the text: A critical introduction to the theory and practice of literary interpretation. Harvester Wheatsheaf, 1990.

[10] Y. E. Nugroho, "Hermeneutika sebuah Tawaran Model Pemahaman bagi Manuskrip Indonesia," in Seminar Sehari; Teori Sastra dan Penerapannya, 2000.

[11] R. E. Palmer, "Hermeneutika: Teori Baru Mengenai Interpretasi, terj," Musnar Hery dan Damanhuri Muhammaed, cet, vol. 2, 2005.

[12] N. K. Ratna, "Penelitian Sastra: Teori, Metode, dan Teknik," Yogyakarta: Pustaka Pelajar, 2004.

[13] R. Ruhyana and N. Elkabumaini, Panduan Implement Pendidikan Budi Pekerti. Yogyakarta: Yrama Widya, 2016.

[14] A. A. Soebachman, Buku Pintar Raja/Tokoh Keraton, dan Candi di Tanah Jawa. Yogyakarta: Syura Media Utama, 2016.

[15] A. Hadi, "MW, Hermeneutika Sastra Barat dan Timur." Jakarta: Pusat Bahasa. Depdiknas, 2008. 